\title{
Letters
}

\section{Histological variations of Testicular biopsies from Infertile men with Azoospermia in Jakarta.}

To the Editor.--- Testicular biopsies from 61 cases of infertile men with azoospermia which were referred from several hospitals around the Jabotabek (JakartaBogor-Tangerang-Bekasi) area between 1992 and 1997 to the laboratory of the Biological Department, Faculty of Medicine, University of Indonesia, Jakarta, were analyzed. Ages of the patients ranged between 27 and 60 years. Exact assessment of azoospermic and oligospermic patients through microscopic investigation of testicular biopsies is essential especially to the andrologists ${ }^{1,2}$ A hundred and twenty two testicular biopsies from 61 cases of azoospermic patients with normal sized testes with normal consistency, palpable vas and normal serum levels of follicle stimulating hormone (FSH) were obtained. Microscopic investigation were done to differentiate between obstructive azoospermia and primary seminiferous tubular failure. $^{3}$

The 122 testicular biopsies were obtained by urologists using open surgery technique, the tissues were fixed in Bouin's fluid, embedded in paraffin and sectioned at $7 \mu \mathrm{m}$ and stained with hematoxylin-eosin. An average of 20 tubules from each testicular slide were scored, and the cathegorization of the testicular biopsies were according to the criteria of de Kretzer \& Holstein, using the 10 histological features of Johnsen. ${ }^{4}$

Evaluation of testicular biopsy from infertile men is essential in deciding the treatment and the prognosis of the patients' condition. We found that the age of most of the infertility cases were above 30 years, which is in accordance with the patients of Pryor, ${ }^{5}$ and
Ramelan. ${ }^{6}$ Our microscopic investigation of the 122 testicular biopsy samples showed $35(28.7 \%)$ samples with normal/near normal testicular tissue, and that hypospermatogenesis were the most frequent abnormal feature $(23.8 \%$ ) found in 29 samples, followed by germinal cell arrest (22.1\%) in 27 samples, immature testis $(10.6 \%)$ found in 13 samples and the least frequent features were the Sertoli-cell-only syndrome (7.4\%), and seminiferous tubule hyalinization (7.4\%), found in 9 samples each. According to our findings it seems that in 12 out of 26 patients which were biopsied on both of their testes, and 11 out of 38 patients biopsied on the left testes only azoospermia were caused by obstruction, and in the other 38 out of the total of 61 cases, azoospermia is likely caused by seminiferous tubule failure.

M. Hatta Syahrum, MD, SpRad, SpAnd Department of Biology, Faculty of Medicine, University of Indonesia, Jakarta.

1. Laihad PF, Himawan S, Marwoto W, Rahardjo D. Penelitian histopatologi biopsi testis untuk prediksi nilai prognostik pada infertilitas. Medika 1990; 7: 533-6.

2. Syahrum MH. Biopsi testis sebagai pengevaluasi pasien azoospermia. (Testicular biopsy as an evaluation of azoospermic patients) MKI 1997; 5: 232-6.

3. Coburn M, Wheeler T, Lipshultz LT. Testicular biopsy. Its use and limitations. Urologic Clinic of North America 14 1987; 3: 551-61.

4. de Kretzer DM, Holstein AF. Testicular biopsy and abnormal germ cells. In: Human semen and fertility regulation in men. Hafez ESE, ed. St. Louis: Mosby; 1976. p. 332-43.

5. Pryor JP. Azoospermia. In: Male infertility. Hargreave TB, ed. Berlin: Springer; 1983: 212-25.

6. Ramelan W. Possible role of parental age on secretory azoospermia. Med J Indones 1998; 7 (2): 65-70. 